\title{
Use of aqueous plant extracts to reduce profenofos residues in the leaf of mustard (Brassica juncea L.) and suppression of the grasshopper population
}

\author{
Mohammad Hoesain $^{1 *}$, Sigit Prastowo ${ }^{1}$, Wagiyana ${ }^{1}$, Ankardiansyah Pandu Pradana ${ }^{1}$, Fariz Kustiawan \\ Alfarisy $^{2} \&$ Muh Adiwena ${ }^{3}$ \\ ${ }^{1}$ Department of Plant Protection, Agriculture Faculty, Universitas Jember. Jl. Kalimantan No. 37, Kampus Tegalboto, Jember 68121, Jawa Timur, \\ Indonesia \\ ${ }^{2}$ Agricultural Sciences Department, Postgraduate Program Faculty of Agriculture, Universitas Jember. Jl. Kalimantan No. 37, Kampus \\ Tegalboto, Jember 68121, Jawa Timur, Indonesia \\ ${ }^{3}$ Agrotechnology Department, Agriculture Faculty, Universitas Borneo Tarakan. Jl. Amal Lama No. 1 Kelurahan Pantai Amal, Kota Tarakan \\ 77123, Kalimantan Utara, Indonesia \\ *Email: hoesain.faperta@unej.ac.id
}

ARTICLE HISTORY

Received: 19 March 2021

Accepted: 28 May 2021

Available online: 01 July 2021

\section{KEYWORDS}

Centella asiatica

Luffa acutangula

Phytotoxic

Sapindus rarak

UPLC-MS/MS
ABSTRACT

Profenofos is an active ingredient from the organophosphate group which residue is often found in various fresh and processed vegetable products. This study aimed to assess the use of aqueous plant extracts of Sapindus rarak seeds, Luffa acutangula peel and Centella asiatica leaves to reduce profenofos residues in leaf of mustard and to evaluate their performance in suppressing the grasshopper populations. S. rarak seeds, L. acutangula peels and C. asiatica leaves were dried and filtered using a 100 mesh sieve. A total of $30 \mathrm{gm}$ samples of each ingredient were mixed with $1000 \mathrm{ml}$ of water and blended at $800 \mathrm{rpm}$, then filtered using 100 mesh sieve before use. The field experiment was performed by spraying profenofos pesticide with a concentration of $3 \mathrm{ml} \mathrm{l}^{-1}$ at a dose of $30 \mathrm{ml}$ per plant. Two days after the profenofos application, the plants were sprayed with the aqueous plant extracts. Twenty-four hrs aqueous plant extracts application, pesticide residues were detected by the UPLC-MS/MS machine. The phytotoxicity test results showed that the use of aqueous plant extracts at a dose of $30 \mathrm{ml}$ per plant did not cause any phytotoxic symptoms. Furthermore, in the field experiment, the control plants showed a residual value of $2407.62 \mathrm{ng} \mathrm{g}^{-1}$. Results of UPLC-MS/MS showed that the residual value of profenofos in PL treatment (aqueous extract of $S$. rarak seeds) was $1502.05 \mathrm{ng} \mathrm{g}^{-1}$, the recorded residual value in the PP treatment (aqueous extract of $C$. asiatica leaves) was $1316.27 \mathrm{ng} \mathrm{g}^{-1}$ and the residual value in the PG treatment (aqueous extract of L. acutangula peels) was $660.71 \mathrm{ng} \mathrm{g}^{-1}$. In the treated plants, the residual value decreased from $37.48 \%$ to $72.55 \%$. Furthermore, the number of grasshoppers after the PL treatment decreased and was significantly different from the control. This study provides new information that aqueous plant extracts can reduce the residue of profenofos and suppress the population of grasshoppers in the mustard leaf.

\section{Introduction}

The application of synthetic chemical pesticides in Indonesia has now reached an alarming level. The use of chemical pesticides is a means of controlling Plant Pest Organisms (PPO), which farmers in Indonesia most widely use $(95.29 \%)$ because it is considered effective, easy to use and economically profitable (1). The use of pesticides on agricultural land and plantations occurs from the beginning to the end of the cropping cycle, starting from soil processing, land preparation, plant maintenance, harvesting and even post-harvest $(2,3)$. Although pesticides benefit in controlling pests and plant diseases, it needs to be considered its disadvantage: pesticides are bioactive chemicals and are toxic (4). Every poisonous ingredient possesses dangers and harmful in its use, both to the environment and humans (5).

The research results on 315 samples of agricultural products reported that pesticide residues were found in $47 \%$ of fresh product samples and $7 \%$ of processed food samples $(6,7)$. Meanwhile, it was reported that pesticide residues were found in $65 \%$ of fresh product samples and $10 \%$ of processed vegetable samples (8). Those researches indicate that there are still many pesticide residues left in the plants' given

(c) Hoesain et al (2021). This is an open-access article distributed under the terms of the Creative Commons Attribution License, which permits unrestricted use, distribution and reproduction in any medium, provided the original author and source are credited (https://creativecommons.org/licenses/by/4.0/) 
pesticides. The residue is a substance or residual compound from pesticides that is left on the human, animal, plant, air, water and soil tissues. Some of the research results of horticultural crops in the vegetable category ranging from mustard, tomatoes, chilies, cabbage and shallots, detected chlorpyrifos insecticide residues with a value of $0.45 \mathrm{mg} \mathrm{kg}^{-1}$ (911).

The residue contained in plants can come from pesticide spraying on the plants. Insecticide residues are present in all plant parts, such as stems, leaves, fruits and roots. Especially for fruit, this residue is present on the surface and flesh of the fruit $(12,13)$. Even though it has been washed or cooked, this pesticide residue is still present in food ingredients (14). The organophosphate group is the largest amount of pesticides on the market and is widely used in agriculture. It gives a satisfying effect with a low dose; besides, it works quickly and is easily broken down. Organophosphate poisoning can occur by mouth, inhalation and skin. In the body, the organophosphate binds to the acetylcholinesterase (AChE) enzyme, which results in the build-up of acetylcholine in nerves (15). Profenofos is a type of organophosphate insecticide with a maximum residue limit of $5 \mathrm{mg} \mathrm{kg}^{-1}$ in horticultural products as required by the Indonesian National Standard (16).

The use of alternative pests and plant disease control techniques such as biopesticides and botanical pesticides is currently not very popular among farmers (17). Most farmers prefer to use synthetic chemical pesticides to control pests and plant diseases because they give a fast result and easy to apply (18). Meanwhile, biopesticides and botanical pesticides require a long time and process to be entirely accepted by the farming community (19). Based on this phenomenon, the residual contamination of active pesticide ingredients in conventional agricultural products is complicated to avoid. Concrete solutions are needed to suppress and even remove the residue of active pesticide ingredients that are easy to apply and applied in the field.

Several botanical ingredients such as Sapindus rarak seeds, Luffa acutangula peels and Centella asiatica leaves are reported to contain high saponin content (20-22). Saponins are compounds of the glycoside type. Glycosides are compounds composed of glycons (glucose, fructose) and aglycones (23). Saponins are known as natural detergents, with molecular structure consisting of more than one sugar chain. With its nature as a natural detergent, saponins can dissolve various kinds of substances, including the active pesticide ingredients (24). Generally, one character shown by plants containing saponins is when dissolved or shaken with water will produce foam. The foam that appears is amphipathic glycosides. Foam from this group is stable and does not easily disappear $(25,26)$.

Saponins' ability to dissolve various substances cannot be separated from the natural glycoside components they contain (27). There are two types of natural glycosides in saponins: alcohol triterpenoid glycosides and steroid structural glycosides. Both types of natural glycosides are soluble in water and alcohol but insoluble in ether $(28,29)$. Its watersoluble nature will facilitate application in the field because it does not require special solvents that are potentially difficult to get by the farmers. The use of saponins as on-farm pesticide washing-treatment has not been potentially harmful to plants. This is supported by the statement, saponins not only has dissolving effect, but also is biodegradable and easy to clean using water (30).

In previous studies, saponins from various plant extracts were reported to reduce surface tension (31). The lower the surface tension, the easier the pesticide active ingredients will be washed from agricultural products (24). The use of saponins for on-farm pesticide washing-treatment is a solution that is effective, environmentally friendly, inexpensive and easy for farmers to apply. However, until now, there have been no reports on the use of $S$. rarak, $L$. acutangula and $C$. asiatica as pesticide washing agents directly in the field. The discovery of a pesticide residues washing method in the field will provide a new information and become new recommendations in the context of implementing healthy agriculture.

Apart from being potential as a washing agent for pesticides in the field, the use of aqueous plant extracts also has the potential to reduce pest populations. It was reported that the aqueous extract of $S$. rarak can act as a repellent for some insects (32). In addition, $S$. rarak extract was also reported to be insecticidal against the larvae of Crocidolomia pavonana (33). It was also reported that L. acutangula extract also has the potency as a potential source of botanical pesticides to suppress the population of several types of pests (34). This fact shows that the extracts from the selected plant have a dual potential, namely as a washing agent for pesticides as well as for botanical pesticides. This study is aimed to evaluate the effectiveness of aqueous plant extracts from $S$. rarak seeds, $L$. acutangula peels and $C$. asiatica leaves as a pesticide washing agent as well as its effectiveness in suppressing grasshopper population in leaf of mustard.

\section{Materials and Methods}

\section{Time and Place of Research}

The research was conducted from October 2020 to January 2021. The research was carried out in three places, namely the Laboratory of Plant Pest and Disease Control Technology, in greenhouses, and on the experimental field belonging to the Plant Protection Study Programme, Faculty of Agriculture, University of Jember, Indonesia.

\section{Sources of Plant Materials}

Sources of plant matter, namely $S$. rarak seeds, $L$. acutangula peels and $C$. asiatica leaves were obtained from traditional markets in Jember, East Java, Indonesia. All the materials obtained are clean, so washing is not carried out prior to the drying process. The plant matter obtained was dried in the greenhouse until the water content was $\pm 13-15 \%$. 
The sample drying process was performed carefully to avoid direct sunlight exposure. The dry sample was then chopped and filtered using a 100 mesh sieve.

\section{Producing Aqueous Extracts of Plant Materials}

The aqueous plant extracts was made by mixing 30 gm of chopped plant powder with $1000 \mathrm{ml}$ of water. The final concentraion of the aqueos extract is 30.034 $\mathrm{ppm}$. Mixing was done using a blender at $800 \mathrm{rpm}$ for $5 \mathrm{~min}$. The mixed material was then filtered using a 100 mesh sieve to filter out any residual plant powder that can interfere with the sprayer. The aqueous plant extracts obtained was used for the next test (35).

\section{Phytotoxicity Test}

To ensure that the plant extract used was safe for leaf mustard growth, a phytotoxicity test was carried out. The leaf mustard of the Tosakan variety was planted in polybags with $15 \times 30 \mathrm{~cm}$ in a greenhouse. The test was carried out following a completely randomized design pattern with 4 treatments, 5 replications and each replication consisting of 3 test plants. The treatment used was the aqueous plant extracts and water was used as a control. One week after transplanting, the leaf of mustard were sprayed with $100 \mathrm{ml}$ of each treatment's aqueous plant extract. After being given the treatment, the leaf mustard were kept for 3 weeks while observing their development. Phytotoxicity is characterized by the appearance of symptoms such as stunted growth, wilting of the leaves, necrosis or chlorosis on the leaves, shriveled leaves and other abnormal growth symptoms (36).

\section{Field Experiment}

The leaf mustards of the Tosakan variety were planted on the soil beds in the University of Jember experimental field. The leaf mustard plant was chosen as the test plant because it has a large leaf surface making it easier to be assessed. The test was performed following a randomized block design pattern with 4 treatments, 3 replications and each replication consisting of 20 tested plants. Three weeks after transplanting, the leaf mustard plants were sprayed using synthetic chemical pesticides contain active ingredient profenofos. The pesticide concentration used was $3 \mathrm{ml} \mathrm{l}^{-1}$. The sprayed dose of synthetic chemical pesticides was $600 \mathrm{ml}$ per bed (equivalent to $30 \mathrm{ml}$ per plant).

Two days after the application of synthetic chemical pesticides, the plants were sprayed using aqueous plant extracts. The aqueous plant extracts concentration $3 \%$ at a dose of $600 \mathrm{ml}$ per bed (equivalent to $30 \mathrm{ml}$ per plant). Furthermore, the treatments used in the field experiment are presented in Table 1.

Twenty-four hrs after the application of aqueous plant extracts, leaf samples from each treatment were taken and placed in plastic placed in an icebox. The sample was brought to the laboratory for analysis of pesticide residues. In the field experiment, the observed variables observed were pesticide residues attached to mustard leaves and grasshopper populations after the application of aqueous plant extracts.

Table 1. Treatments used in the study

\begin{tabular}{ll}
\hline Code & Treatment \\
\hline $\mathrm{K}$ & Profenofos insecticide \\
\hline $\mathrm{PL}$ & $\begin{array}{l}\text { Profenofos insecticide }+ \\
\text { aqueous extract of } S . \text { rarak seeds }\end{array}$ \\
\hline PG & $\begin{array}{l}\text { Profenofos insecticide }+ \\
\text { aqueous extract of } L . \text { acutangula peels }\end{array}$ \\
\hline PP & $\begin{array}{l}\text { Profeonofos insecticide }+ \\
\text { aqueous extract of } C \text {. asiatica leaves }\end{array}$ \\
\hline
\end{tabular}

\section{Pesticide Residue Analysis}

Sample extraction was performed on treated leaf mustard samples. Samples in each treatment were blended, then weighed $15 \mathrm{gm}$ in a $50 \mathrm{ml}$ centrifuge tube. The $15 \mathrm{ml}$ of acetonitrile were then added, shaken for 2 min until homogeneous. After that, $6 \mathrm{gm}$ of $\mathrm{MgSO}_{4}$ and $15 \mathrm{gm}$ of sodium acetate were added. The mixture was shaken for $1 \mathrm{~min}$ and centrifuged for $1 \mathrm{~min}$ at $6000 \mathrm{rpm}$. The supernatant formed was taken as much as $8 \mathrm{ml}$, then transferred to a $10 \mathrm{ml}$ centrifuge tube containing $150 \mathrm{mg} \mathrm{MgSO}_{4}, 50 \mathrm{mg}$ PSA, and $50 \mathrm{mg} \mathrm{C} \mathrm{C}_{18}$, then shaken vigorously for 30 seconds. The mixture was then homogenized with vortex for 1 min and centrifuged for $5 \mathrm{~min}$ at a speed of 6000 rpm. A total of $1 \mathrm{ml}$ of the formed supernatant was taken and put into the LC vial to be injected into the UPLC-MS/MS machine (Shimadzu LCMS MS-8060). The pesticide standard used in this research is chlorpyrifos solution analytical standard $(99 \%$, Chem Service, USA). The standard series is made in the range $1-100 \mu \mathrm{g}$ as many as 8 points $(1 ; 2.5 ; 10 ; 20 ; 40$; $\left.80 ; 100 \mathrm{~g} \mathrm{l}^{-1}\right)$. The standard solution was stored at -20 ${ }^{\circ} \mathrm{C}$ until analysis $(37,38)$.

\section{Data Analysis}

Phytotoxicity data are presented in descriptive form by explaining whether or not the observed symptoms appear. Furthermore, pesticide residue data is presented in quantitative form by presenting the residual value results from the UPLC-MS/MS method analysis. Grasshopper population data after the application of aqueous plant extracts were analyzed using one way analysis of variance (ANOVA), if there was data diversity followed by further analysis using Duncan's Multiple Range Test (DMRT) with a 95\% confidence level.

\section{Results and Discussion}

\section{Phytotoxicity of Plant Extracts}

Based on the phytotoxicity test, it is known that all aqueous plant extracts used in this study are safe and do not cause phytotoxicity. Compared with control plants, application of aqueous plant extracts with a concentration of $3 \%$ did not cause a significant change in the treated plants. All plants showed normal growth were indicated by no symptoms of stunted growth, wilting of the leaves, necrosis or chlorosis appearing on the leaves, shriveled leaves, and other abnormal growth symptoms. Furthermore, 
the results of phytotoxicity observations are presented in Table 2 .

Table 2. Phytotoxicity observation results

\begin{tabular}{lccc}
\hline Symptoms & S. rarak & L. acutangula & C. asiatica \\
\hline Stunted growth & - & - & - \\
\hline Withered & - & - & - \\
\hline Necrosis & - & - & - \\
\hline Chlorosis & - & - & - \\
\hline Shriveled leaves & - & - & - \\
\hline Description: (-) no symptoms appeared &
\end{tabular}

Aqueous plant extracts applied in this study did not show any phytotoxicity reactions. Phytotoxic symptoms tend to occur in plants treated with extracts. Extracts usually consist of many combined compounds. Apart from the active compounds, the crude extract also contains other components (39). Methanol extract can consist of a polar component to a nonpolar component. Nonpolar components in oil or concentrated liquids form can damage the wax cuticle of leaves or plant leaf cell membranes (40).

In this study, the absence of phytotoxic effects was suspected due to the ingredients used did not cause cell damage, and the low concentrations used. The active compounds found in $S$. rarak extract include flavonoids, alkaloids, saponins, tannins and polyphenols (41). Meanwhile, $C$. asiatica leaf extract is also reported to contain several active compounds, such as saponins, asiaticocides, thankunicides, isotancunicides, madecassocides, brahmocides, brahminocides, brahmic acids, madasiatic acids, meso-inositol, centellosides, carotenoids, hydrochotillin, vellarine, tannins and mineral salts, such as potassium, sodium, magnesium, calcium and iron (42). The L. acutangula extract is reported to contain some active compounds, such as saponins and antioxidants (43). All ingredients in the three extracts are not dangerous or cause phytotoxic at low concentrations.

\section{The Effect of Plant Aqueous Extract on Profenofos Residue}

Based on the results of analysis in profenofos residue using the UPLC-MS/MS method, profenofos residue of $2407.62 \mathrm{ng} \mathrm{g}^{-1}$ was found in the control plants (without treatment). The residual value in plants treated with plant extract spraying two days after the application of active ingredient profenofos contained pesticide was shown to be lower than that of the control plants. In the PL treatment, it was found that the detected residue value of profenofos was 1502.05 ng g-1, recorded a decrease of $37.48 \%$ compared to the residual value in control plants. Furthermore, in the PP treatment, the detected residue value of profenofos was $1316.27 \mathrm{ng}$ g1, lower than the PL treatment. When compared with the control, the PP treatment gave $45.32 \%$ suppression of the profenofos residue. The highest emphasis was found in plants treated with PG, with a profenofos residual value of $660.71 \mathrm{ng} \mathrm{g}^{-1}$, PG treatment gave an emphasis of $72.55 \%$ compared to controls. From these data it can be concluded that the application of plant extract two days after the application of synthetic chemical pesticides can suppress the of profenofos residues in leaf of mustard. The highest suppression was seen in the aqueous extract of $C$. asiatica leaves treatment. In addition, the data on the profenofos residue on the various treatments tested and the suppression percentage are presented in Table 3.

Table 3. Reduction of profenofos residues in each tested treatment

\begin{tabular}{lll}
\hline Treatment & Residual Value (ng $\left.\mathbf{~}^{-1}\right)$ & $\begin{array}{l}\text { Residue } \\
\text { Reduction (\%) }\end{array}$ \\
\hline K & 2407.62 & 0 \\
\hline PL & 1502.05 & 37.48 \\
\hline PP & 1316.27 & 45.32 \\
\hline PG & 660.71 & 72.55 \\
\hline
\end{tabular}

The three aqueous plant extracts tested were effective in suppressing the residues of profenofos pesticides on leaf mustard. The suppression effect occurred due to the washing activity of the profenofos residue on the leaf mustard. One of the compounds playing an important role in washing pesticide residues is saponins (44). The three plant aqueous extract tested were reported to contain saponins. Saponins are glycosides that have aglycones in the form of sapogenins (29). In previous research, it was reported that saponins can reduce water surface tension (31). This phenomenon of decreasing water surface tension causes saponins to form foam on the water surface after being shaken. This property is known for its similarities with surfactant properties. The decrease in surface tension is caused by the presence of soap compounds that break the hydrogen bonds of water (45). In general, the glycone part of saponins consists of sugars such as glucose, fructose and other types of sugar (23). Meanwhile, the aglycone part consists of sapogenins. The amphiphilic nature of saponins is what causes saponins to have the potential as natural ingredients that can function as surfactants (46).

Surfactants are generally used in soap production. Surfactants are molecules with a hydrophilic group and a lipophilic group. The combination of these two groups can unite a mixture of water and oil (47). This property is thought to be the reason why aqueous plant extracts used in this study can wash or dissolve the active ingredients profenofos. Surfactant molecules have a polar part that likes water (hydrophilic) and a non-polar part that likes oil/fat (lipophilic). The polar parts of the surfactant molecule can be positive, negative or neutral (48).

\section{Effect of Aqueous Plant Extracts Applications on Grasshopper Populations}

Based on the results of observations on the grasshopper population after application of aqueous plant extracts, the results obtained were quite diverse. In control plants, the average grasshopper population found after application of aqueous plant extracts was $4.67 \pm 1.41$. The treatment that gave the highest suppression was PL with an average observed grasshopper population of $1.44 \pm 1.42$. When compared with control plants, PL treatment suppressed grasshopper population by $69.16 \%$. The PL treatment was the only treatment that gave significantly different results compared to control plants. The second highest suppression was given by the PG treatment and PP, with an average of 
grasshopper population values of $3.22 \pm 2.05$ and 3.67 \pm 1.66 respectively. Although the population found in the PG and PP treatments was lower than that of the control plants, statistically the PG and PP treatments were not significantly different from the controls. The data regarding the grasshopper population is presented in Fig. 1.

Apart from being effective in suppressing profenofos residues, the application of aqueous $S$.

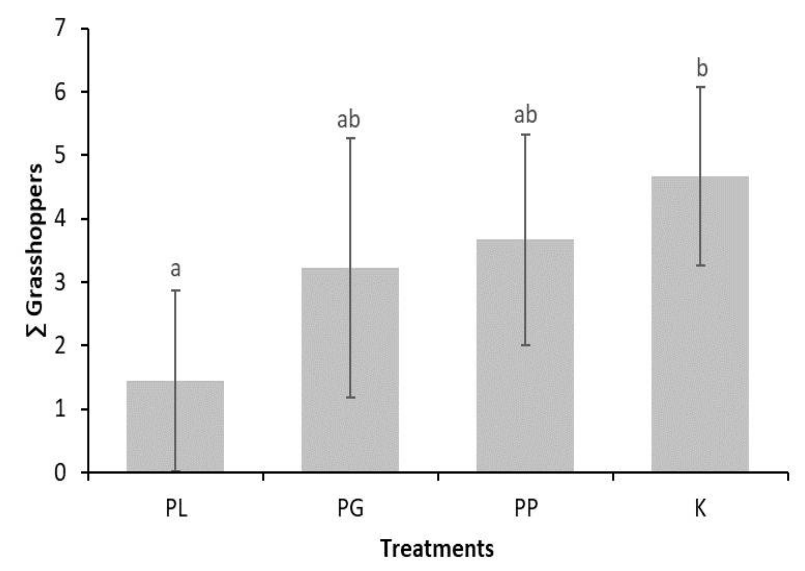

Fig. 1. The observed population of grasshoppers after aqueous plant extracts application.

rarak extract was also known to be effective in suppressing the grasshopper population in this study. The use of $S$. rarak extract to control several pests has been previously reported. For example, it was reported that $S$. rarak extract was effective in controlling pests of golden snails (Pomacea canaliculata) in rice (49). In a separate report, treatment with an aqueous extract of $0.80-3.80 \%$ resulted in $10-100 \%$ mortality of Crocidolomia pavonana larvae with the $\mathrm{LC}_{50}$ of $1.681 \%$ (50). On the other hand, there are reports on the application of lerak extract at the same concentration could result in $1-94 \%$ mortality of $C$. pavonana larvae with the $\mathrm{LC}_{50}$ of $1.898 \%$ (33). Although effective in controlling some pests, reports of $S$. rarak extract for controlling grasshopper populations in the field are still very rare. Other aqueous plant extracts used in this study could not statistically suppress the grasshopper population in the field, presumably because they do not contain compounds that can control grasshoppers, or the concentrations used are not optimal for controlling grasshopper populations.

\section{Conclusion}

This study provided new information that the application of aqueous exracts from $S$. rarak seeds, $L$. acutangula peels and $C$. asiatica leaves with a concentration of $3 \%$ and a dose of $30 \mathrm{ml}$ per plant can reduce the prefenofos residue in leaf mustard by $37.48 \%$ to $72.55 \%$. The highest emphasis was obtained on plants treated using aqueous extract of L. acutangula bark (72.55\%). Apart from being effective in suppressing pesticide residues, the application of $S$. rarak aqueous extract was also effective in suppressing the grasshopper population in mustard leaf.

\section{Acknowledgements}

This research was funded by the University of Jember through the scheme "Research Group Research Grant (Hibah Penelitian Kelompok Riset/KeRis)" with contract number/agreement: 3509/UN.25.3.1/LT/2020.

\section{Authors' contributions}

All authors have a balanced contribution in designing research concepts, conducting experiments, analyzing data and writing the manuscript.

\section{Conflict of interests}

The authors confirmed that this study was conducted without any conflict of interest.

\section{References}

1. Mariyono J, Kuntariningsih A, Kompas T. Pesticide use in Indonesian vegetable farming and its determinants. Manag Environ Qual. 2018;29(2):305-23. https://doi.org/10.1108/MEQ12-2016-0088

2. Atreya K, Sitaula BK, Bajracharya RM. Pesticide use in agriculture: the philosophy, complexities and opportunities. $\begin{array}{lll}\text { Sci } & \text { Res } & \text { Essays. }\end{array}$ https://doi.org/10.5897/SRE10.107

3. Hoi PV, Mol AP, Oosterveer P, van den Brink PJ, Huong PT Pesticide use in Vietnamese vegetable production: a 10-year study. Int J Agric Sustain. 2016;14(3):325-38. https://doi.org/10.1080/14735903.2015.1134395

4. Storck V, Karpouzas DG, Martin-Laurent F. Towards a better pesticide policy for the European Union. Sci Total Environ. 2017;575:1027-33.

https://doi.org/10.1016/j.scitotenv.2016.09.167

5. Yadav IC, Devi NL. Pesticides classification and its impact on human and environment. Environ Sci Eng. 2017;6:140-58.

6. Buyang Y, Pasaribu Y. Analisis residu pestisida golongan piretroid pada beberapa sayuran di Kota Merauke. Agricola. 2014;4(1):41-48. https://doi.org/10.35724/ag.v4i1.312

7. Sumiati A, Julianto RPD. Analisa residu pestisida di Wilayah Malang dan penanggulanganya untuk keamanan pangan buah jeruk. Buana Sains. 2019;18(2):125-30. https://doi.org/10.33366/bs.v18i2.1185

8. Ahmed A, Randhawa MA, Yusuf MJ, Khalid N. Effect of processing on pesticide residues in food crops: a review. J Agric Res. 2011;49(3):379-90.

9. Harsanti ES, Martono E, Sudibyakto H, Sugiharto E. Residu insektisida klorpirifos dalam tanah dan produk bawang merah Allium ascalonicum L., di sentra produksi bawang merah di Kabupaten Bantul, Yogyakarta. Ecolab. 2015;9(1):26-35.

https://doi.org/10.20886/jklh.2015.9.1.26-35

10. Jallow MF, Awadh DG, Albaho MS, Devi VY, Ahmad N Monitoring of pesticide residues in commonly used fruits and vegetables in Kuwait. Int J Environ Res Public Health. 2017;14(8):833. https://doi.org/10.3390/ijerph14080833

11. Panuwet P, Siriwong W, Prapamontol T, Ryan PB, Fiedler N, Robson MG, et al. Agricultural pesticide management in Thailand: status and population health risk. Environ Sci Policy.

https://doi.org/10.1016/j.envsci.2011.12.005
2012;17:72-81. 
12. Del Prado-Lu JL. Insecticide residues in soil, water and eggplant fruits and farmers' health effects due to exposure to pesticides. Environ Health Prev Med. 2015;20(1):53-62. https://doi.org/10.1007/s12199-014-0425-3

13. Wang P, Rashid M, Liu J, Hu M, Zhong G. Identification of multi-insecticide residues using GC-NPD and the degradation kinetics of chlorpyrifos in sweet corn and soils. Food Chem. 2016;212:420-26.

https://doi.org/10.1016/j.foodchem.2016.05.008

14. Rodrigues AA, De Queiroz MEL, De Oliveira AF, Neves AA, Heleno FF, Zambolim $\mathrm{L}$ et al. Pesticide residue removal in classic domestic processing of tomato and its effects on product quality. J Environ Sci Health B. 2017;52(12):850-57. https://doi.org/10.1080/03601234.2017.1359049

15. Kazemi M, Tahmasbi AM, Valizadeh R, Naserian AA, Soni A. Organophosphate pesticides: a general review. Agri Sci Res J. 2012;2(9):512-22.

16. Dalimunthe KT. Analisa kuantitatif residu insektisida profenofos pada cabai merah segar dan cabai merah giling di beberapa pasar tradisional Kota Medan Tahun 2012. Lingkungan dan Keselamatan Kerja. 2012;1(1):1-5.

17. Olson S. An analysis of the biopesticide market now and where it is going. Outlooks Pest Manag. 2015;26(5):203-06. https://doi.org/10.1564/v26_oct_04

18. Ivase TJ-P, Nyakuma BB, Ogenyi BU, Balogun AD, Hassan MN. Current status, challenges and prospects of biopesticide utilization in Nigeria. Acta Univ Sapientiae Agric Environ. 2017;9(1):95-106.

19. Dar SA, Khan Z, Khan AA, Ahmad SB. Biopesticides-ts Prospects and Limitations: An Overview. Perspective in Animal Ecology and Reproduction. New Delhi, India: Astral International (P) Ltd. 2019:296-314.

20. Al-Snafi AE. A review on Luffa acutangula: a potential medicinal plant. Magnesium. 2019;9(9):56-67.

21. Mangas S, Moyano E, Osuna L, Cusido RM, Bonfill M, Palazón J. Triterpenoid saponin content and the expression level of some related genes in calli of Centella asiatica. Biotechnol Lett. 2008;30(10):1853-59. https://doi.org/10.1007/s10529-008-9766-6

22. Yuliana P, Laconi E, Jayanegara A, Achmadi S, Samsudin A. Extracted saponin from Sapindus rarak and Hibiscus sp. as an additive in cassava leaf silage: effects on chemical composition, rumen fermentation and microbial population. Adv Anim Vet Sci. 2019;7(7):530-36. http://dx.doi.org/10.17582/journal.aavs/2019/7.7.530.536

23. Moghimipour E, Handali S. Saponin: properties, methods of evaluation and applications. Annu Res Rev Biol. 2015;5(3):207-20. https://doi.org/10.9734/ARRB/2015/11674

24. Wisetkomolmat J, Suppakittpaisarn P, Sommano SR. Detergent plants of Northern Thailand: potential sources of natural saponins. Resources. 2019;8(1):10. https://doi.org/10.3390/resources8010010

25. Forey N, Atteia O, Omari A, Bertin H. Saponin foam for soil remediation: on the use of polymer or solid particles to enhance foam resistance against oil. J Contam Hydrol. 2020;228:103560 https://doi.org/10.1016/j.jconhyd.2019.103560

26. Asif M, Tariq M, Khan A, Rehman B, Parihar K, Siddiqui MA. Potential role of aqueous extract of some weeds against egg hatching and juvenile mortality of root-knot nematode Meloidogyne incognita. J Agric Crop. 2017;3(2):17-24.

27. Tang J, He J, Liu T, Xin X. Removal of heavy metals with sequential sludge washing techniques using saponin: optimization conditions, kinetics, removal effectiveness, binding intensity, mobility and mechanism. RSC Adv 2017;7(53):33385-401. https://doi.org/10.1039/C7RA04284A

28. Challinor VL, De Voss JJ. Open-chain steroidal glycosides, a diverse class of plant saponins. Nat Prod Rep. 2013;30(3):42954. https://doi.org/10.1039/c3np20105h

29. El Aziz M, Ashour A, Melad A. A review on saponins from medicinal plants: chemistry, isolation and determination. Nanomed Res. https://doi.org/10.15406/jnmr.2019.07.00199
30. Liu Z, Li Z, Zhong H, Zeng G, Liang Y, Chen M, et al. Recent advances in the environmental applications of biosurfactant saponins: a review. J Environ Chem Eng. 2017;5(6):6030-38. https://doi.org/10.1016/j.jece.2017.11.021

31. Böttger S, Hofmann K, Melzig MF. Saponins can perturb biologic membranes and reduce the surface tension of aqueous solutions: a correlation?. Bioorg Med Chem. 2012;20(9):2822-28. https://doi.org/10.1016/j.bmc.2012.03.032

32. Fauziah RS, Sudarsono S, Mulyaningsih B. Larvicidal activity of the mixture of cashew nut shell liquid (CNSL) and aqueous extract of Sapindus rarak DC. against larvae of Culex quinquefasciatus. Bio Med Nat Prod Chem. 2014;3(1):21-23. https://doi.org/10.14421/biomedich.2014.31.21-23

33. Syahroni YY, Prijono D. Aktivitas insektisida ekstrak buah Piper aduncum L. (Piperaceae) dan Sapindus rarak DC. (Sapindaceae) serta campurannya terhadap larva Crocidolomia pavonana (F.) (Lepidoptera: Crambidae). J Entomol Indones. https://doi.org/10.5994/jei.10.1.39

2015;10(1):39-50.

34. Soam PS, Singh T, Vijayvergia R. Citrullus colocynthis (Linn.) and Luffa acutangula (L.) Roxb. source of bioinsecticides and their contribution in managing climate change. Intl J Appl Biol Pharm Tech. 2013;4(4):7-9.

35. Degri MM, Mailafiya DM, Wabekwa JW. Efficacy of aqueous leaf extracts and synthetic insecticide on pod-sucking bugs infestation of cowpea (Vigna unguiculata (L.) Walp) in the Guinea Sa-vanna Region of Nigeria. Adv Entomol. 2013;1(2): 10-14. https://doi.org/10.4236/ae.2013.12003

36. Shahi SK, Patra M, Shukla A, Dikshit A. Use of essential oil as botanical pesticide against post harvest spoilage in Malus pumilo fruit. Biocontrol. 2003;48(2):223-32. https://doi.org/10.1023/A:1022662130614

37. Chamkasem N, Ollis LW, Harmon T, Lee S, Mercer G. Analysis of 136 pesticides in avocado using a modified QuEChERS method with LC-MS/MS and GC-MS/MS. J Agri Food Chem. 2013;61(10):2315-29. https://doi.org/10.1021/jf304191c

38. Guo J, Tong M, Tang J, Bian H, Wan X, He L, et al. Analysis of multiple pesticide residues in polyphenol-rich agricultural products by UPLC-MS/MS using a modified QuEChERS extraction and dilution method. Food Chem. 2019;274:452-59. https://doi.org/10.1016/j.foodchem.2018.08.134

39. Datta R, Kaur A, Saraf I, Singh IP, Kaur S. Effect of crude extracts and purified compounds of Alpinia galanga on nutritional physiology of a polyphagous lepidopteran pest, Spodoptera litura (Fabricius). Ecotoxicol Environ Saf 2019;168:324-29. https://doi.org/10.1016/j.ecoenv.2018.10.065

40. Werrie P-Y, Durenne B, Delaplace P, Fauconnier M-L. Phytotoxicity of essential oils: opportunities and constraints for the development of biopesticides a review. Foods. 2020;9(9):1291. https://doi.org/10.3390/foods9091291

41. Singh R, Sharma B. Phytochemical analysis and pharmaceutical development from sapindus spp. Biotechnological Advances, Phytochemical Analysis and Ethnomedical Implications of Sapindus species: Springer; 2019. p. 55-88

42. Arumugam T, Ayyanar M, Pillai YJK, Sekar T. Phytochemical screening and antibacterial activity of leaf and callus extracts of Centella asiatica. Bangladesh J Pharmacol 2011;6(1):55-60. https://doi.org/10.3329/bjp.v6i1.8555

43. Suryanti V, Marliyana S, Astuti I (editors). Chemical constituents of Luffa acutangula (L.) Roxb. fruit. IOP Conference Series: Materials Science and Engineering; 2017: IOP Publishing.

44. Venkatachalapathy $R$, Anoop Chandra IR, Das S, Vajiha Aafrin B, Lalitha Priya U, Peter MJ et al. Effective removal of organophosphorus pesticide residues in tomatoes using natural extracts. J Food Process Eng. 2020;43(2):e13351. https://doi.org/10.1111/jfpe.13351

45. Chen YF, Yang $\mathrm{CH}$, Chang MS, Ciou YP, Huang YC. Foam properties and detergent abilities of the saponins from Camellia oleifera. Int J Mol Sci. 2010;11(11):4417-25. https://doi.org/10.3390/ijms11114417

46. Schmitt C, Grassl B, Lespes G, Desbrières J, Pellerin V, Reynaud S et al. Saponins: a renewable and biodegradable 
surfactant from its microwave-assisted extraction to the synthesis of monodisperse lattices. Biomacromolecules. 2014;15(3):856-62. https://doi.org/10.1021/bm401708m

47. Kralova I, Sjöblom J. Surfactants used in food industry: a review. J Disper Sci Technol. 2009;30(9):1363-83. https://doi.org/10.1080/01932690902735561

48. De S, Malik S, Ghosh A, Saha R, Saha B. A review on natural surfactants. RSC advances. 2015;5(81):65757-67.

49. Mayasari SL. Pemanfaatan Getah Biduri (Calotropis gigantea) dan Buah Lerak (Sapindus rarak) Sebagai Pestisida Nabati Pembasmi Keong Mas (Pomacea canaliculata L.) [Thesis] Surakarta (INA): Universitas Muhammadiyah Surakarta; 2016.

50. Irawan R. Toksisitas Campuran Ekstrak Daun Tephrosia vogelii (Leguminosae) dan Buah Sapindus rarak (Sapindaceae) terhadap Larva Crocidolomia pavonana [Thesis]. Bogor (INA): IPB University. 2012.

\section{Additional information}

Peer review information: Plant Science Today thanks Sectional Editor and the other anonymous reviewers for their contribution to the peer review of this work.

Reprints and permissions information is available at

https://horizonepublishing.com/journals/index.php/PST/open_access_policy

Publisher's Note: Horizon e-Publishing Group remains neutral with regard to jurisdictional claims in published maps and institutional affiliations.

To cite this article: Hoesain M, Prastowo S, Wagiyana, Pradana A P, Alfarisy F $\mathrm{K}$, Adiwena $\mathrm{M}$. Use of aqueous plant extracts to reduce profenofos residues in the leaf of mustard (Brassica juncea L.) and suppression of the grasshopper population. Plant Science Today. 2021;8(3):674-680. https://doi.org/10.14719/pst.2021.8.3.1173

Plant Science Today, published by Horizon e-Publishing Group, is covered by Scopus, Web of Science, BIOSIS Previews, Clarivate Analytics, etc. See https://horizonepublishing.com/journals/index.php/PST/indexing_abstracting 